Discussion Paper No. 16-024

\title{
On Tax Evasion, Entrepreneurial Generosity and Fungible Assets
}

Benjamin Bittschi, Sarah Borgloh, and Marc-Daniel Moessinger

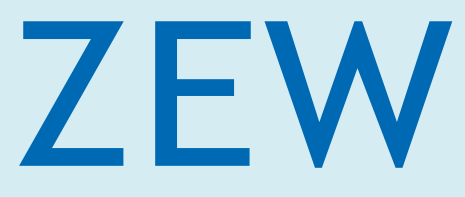

Zentrum für Europäische Wirtschaftsforschung $\mathrm{GmbH}$ Centre for European Economic Research 
Discussion Paper No. 16-024

\title{
On Tax Evasion, Entrepreneurial Generosity and Fungible Assets
}

\author{
Benjamin Bittschi, Sarah Borgloh, \\ and Marc-Daniel Moessinger
}

Download this ZEW Discussion Paper from our ftp server:

http://ftp.zew.de/pub/zew-docs/dp/dp16024.pdf

Die Discussion Papers dienen einer möglichst schnellen Verbreitung von neueren Forschungsarbeiten des ZEW. Die Beiträge liegen in alleiniger Verantwortung der Autoren und stellen nicht notwendigerweise die Meinung des ZEW dar.

Discussion Papers are intended to make results of ZEW research promptly available to other economists in order to encourage discussion and suggestions for revisions. The authors are solely responsible for the contents which do not necessarily represent the opinion of the ZEW. 


\title{
On tax evasion, entrepreneurial generosity and fungible assets
}

\author{
Benjamin Bittschi* \\ (KIT Karlsruhe and ZEW Mannheim) \\ Sarah Borgloh» \\ Marc-Daniel Moessinger ${ }^{\ddagger}$ \\ (ZEW Mannheim)
}

March 2016

\begin{abstract}
We estimate the effects of income from various sources on charitable giving using administrative German income tax data. We demonstrate that charitable contributions are not uniformly affected by different income types. While business and capital income exhibit a positive effect, the remaining income sources do not influence charity on statistically significant levels. This exercise is not new and has been conducted for (at least) three different purposes: 1) Relying on the described results, a public finance researcher would state that business and capital income are more prone to tax evasion than the remaining income sources. 2) An entrepreneurship researcher would conclude that business owners are more generous than employees, and 3) a researcher testing the validity of the life cycle theory (or its behavioral counterpart) would refute the fungibility of income. In contrast, we argue that none of these approaches can answer the intended question if solicitation effects of fundraising or measurement error of the income sources are not taken into account. Applying a fixed effect poisson model, we demonstrate that under certain assumptions the results can have a meaningful interpretation.
\end{abstract}

JEL Classification: D91, E21, H26, H41, L26

Keywords: tax evasion, entrepreneurial behavior, charitable giving, income fungibility, administrative data, fixed effects poisson model

*Corresponding author. Contact: Kronenstraße 34, 76133 Karlsruhe, Germany, 0049721 608-43731, benjamin.bittschi@kit.edu.

$\diamond$ Contact: sborgloh@yahoo.de.

$\ddagger$ Contact: moessinger@zew. de.

We are grateful to Astrid Pennerstorfer, Johannes Voget and participants in various conferences and seminars for helpful comments and suggestions. Moreover, we thank Melanie Scheller and Stefanie Uhrich from the Research Data Center of the German Federal Statistical Office for support in accessing the data. Financial support by the German Research Foundation is gratefully acknowledged. The usual disclaimer applies. 


\section{Introduction}

Do business owners evade more taxes than employees?

Do self-employed donate more to charity than the general population?

Does the life-cycle consumption hypothesis hold?

At first sight these three question seem to be at most loosely related. Yet, economist answer all of these questions by running essentially the same regression:

$$
\text { Donations }=\alpha+\beta_{1} \text { Income source }+\beta_{2} X+\epsilon \text {. }
$$

We use German administrative income tax data and also regress charitable donations on seven different income sources. We find that capital and business income positively influence charitable giving, whereas there are no statistically significant effects for remaining income sources such as employee income, income from agriculture or rental and leasing. This exercise is not new and has been conducted for (at least) three different purposes. Relying on results originating from the estimation of equation (1), 1) researchers in public finance would state that business owners and capital income earners evade more taxes than employees (Feldman and Slemrod 2007). Using the same results, 2) entrepreneurial researchers would conclude that business owners are more generous than employees (Tietz and Parker 2014), while 3) researchers testing the validity of the life cycle theory (or its behavioral counterpart) would refute the fungibility of income (Levin 1998; Steinberg et al. 2010). In contrast, we argue that none of these approaches can answer the intended question.

The first question is a consumption based approach to investigate tax evasion, as pioneered by Pissarides and Weber (1989). Instead of food consumption, however, donations are used as the good of consumption because information on charitable donations is available in administrative tax data and from many surveys. The approach rests crucially on the assumption of a comparable charitable inclination between different income sources. If this holds true, all differences in the effect size of the different income sources on charitable donations can be traced backed to income under-reporting and can, in case of administrative tax data, be interpreted as tax evasion. The presumption of an invariable charitable inclination is, however, 
a strong requirement given that entrepreneurs and wealthy people are more likely to receive charitable solicitations. The fundraising literature regularly addresses the topic of prospect analysis and wealth screening to gain new donors (e.g., Filla and Brown (2013)). Additionally, many professional donor search agencies advertise these capabilities to non-profit organizations, and software companies supply nonprofits with the necessary tools to screen systematically for donors by using publicly available data on real estate wealth, public company insiders and other professionals such as lawyers and medical doctors. ${ }^{1}$ Thus, the assumption of a invariable charitable inclination also implicitly asserts the ineffectiveness of fundraising. However, being asked to donate is known to be a powerful predictor of actual donations (Andreoni and Payne 2013). ${ }^{2}$ Ignoring the different frequencies of charitable solicitations is thus likely to upward bias the estimates and thus to overstate tax evasion.

The second question focuses on comparisons of generosity between earners of business and employment income and has gained some attention in entrepreneurial research against the background on how personality traits of entrepreneurs differ to the 'normal' population. ${ }^{3}$ However, as for the first question, it is important to keep the solicitation effect in mind. Neglecting this effect would upward bias the generosity estimates because they could simply reflect a higher likelihood of being asked and would thus spuriously label entrepreneurs and wealthy people as intrinsically more generous than the rest of the population. Furthermore, measurement errors based on income-underreporting may bias the results. This particularly holds true for underreporting of business income - both for administrative tax data but also for household surveys. For instance, Hurst et al. (2014) provide evidence that the self-employed under-report their income in household surveys by approximately $25 \%$. Ignoring this issue translates into an higher generosity of business owners compared to non-business owners with identical true income and charitable inclination.

The third question tests the life cycle hypothesis, which implies the fungibility of income. In case of charitable donations, this means an equal inclination to donate irrespective of the source

1 See, e.g., the information by Blackbaud Inc., which is a software supplier for nonprofit organizations: https://www.blackbaud.com/files/resources/downloads/WhitePaper_ ProspectResearchForTheNonResearcher.pdf.

2 Andreoni and Rao (2011) also stress the 'power of the ask' effect suggesting that communication, i.e., asking for charitable giving, has an effect on a donors generosity.

3 The general question has been raised, for instance, by Baumol (1990). Concerning selfishness/altruism see, e.g., Weitzel et al. (2010); for charitable giving Tietz and Parker (2014). 
of income. Neither results an additional euro in current salary in a larger increase in donations compared to an additional euro in interest income, nor does an additional euro in business income imply a higher donation compared to an additional euro in income from employment. If this conjecture does not hold, the assumption of fungible income for charitable giving must be rejected. However, as for the previous questions, both measurement errors based on income underreporting and variable charitable inclinations must be taken into account. Otherwise, differing estimates might not reflect differing marginal propensities to consume, but rather misreported income or a differing exposition to fundraising activities.

Improving the research on these three questions, however, is of practical importance. Of course we need to understand the dynamics of tax evasion with respect to different sources of income. To detect the whole extent of tax evasion additional inference from observational or administrative data is necessary, as audits are unable to detect all sources of income underreporting such as cash transaction (Feldman and Slemrod 2007). Scrutinizing entrepreneurial generosity is interesting because it reveals the validity of the claim that a society benefits from its entrepreneurs beyond their influence on economic development. That is, certain personal traits such as, e.g., philanthropy spill over to a socially beneficial behavior (Acs and Phillips 2002). Finally, knowledge about the connection of income fungibility and charitable donations is insightful as it can be suggestive of changes in total giving when it comes to short-term or even structural changes in the composition of income, for example in the context of a crisis. These insights are not only valuable for nonprofit organizations and fundraisers (which are partially financed by donations) in order to facilitate their financial planning, but also for governments whose revenues are affected through the tax deductibility of charitable giving.

We propose a simple solution to control for both, measurement errors in income and the frequency of charitable solicitations. Under the assumption that both effects are time invariant - at least for a short period - they can be treated in an econometric investigation as unobserved heterogeneity and thus do not constitute an omitted variable bias any longer. We admit that assuming both effects as temporary time invariant is still an assumption, nevertheless, it improves the current state of research as it discloses the assumption and hence enables a meaningful interpretation for the results of the estimation of equation (1). Additionally, we suggest directions to further improve research on the topics at hand. 
In order to implement tax unit fixed effects, we estimate a fixed effects poison model (FEPM) which additionally solves various econometric difficulties inherent in other models so far applied in this context (for a thorough discussion see Section 3 ). ${ }^{4}$

Our paper thus differentiates from the existing literature, which either uses cross-sectional data (Brooks 2002; Feldman and Slemrod 2007$)^{5}$ or bases the estimation on random effects models (Daneshvary and Luksetich 1997; Steinberg et al. 2010; Tietz and Parker 2014). ${ }^{6}$ Furthermore, none of the studies point to the trade-off in studying tax evasion, entrepreneurial generosity, or income fungibility.

The remainder of the paper is structured as follows: In Section 2, we describe the data set and our variables of interest. The estimation strategy and the results are presented in Section 3. Section 4 concludes with a discussion of the results and suggestions for further improvements of this kind of research.

\section{Data}

We base our analysis on the 5\% sample of the German Taxpayer Panel, which is derived from the yearly German Income Tax Statistics by the Federal Statistical Office (FSO). We use the waves from 2001 to 2006, as this period covers several tax reforms (see figure 2) enabling a separate identification of income and tax price effects (Triest 1998). To construct a panel data set, the FSO linked up the observations of the single years according to the individual's tax identification number or other individual identifiers. ${ }^{7}$ The persons that could not be linked up

4 To the best of our knowledge, Reinstein (2011) is the only author applying the FEPM in the context of charitable giving. He does, however, not distinguish between effects from different income sources.

5 Brooks (2002) employs cross-sectional data from the consumer expenditure survey and finds a negatively inelastic reaction of charitable giving to changes in welfare income as opposed to earned income. Feldman and Slemrod (2007) use 1999 U.S. tax return data from the internal revenue service statistics to estimate an unweighted non-linear least squares estimation.

6 Daneshvary and Luksetich (1997) rely on U.S. tax return data from the internal revenue service tax model file and provide results based on standard OLS, OLS random effects, and an OLS fixed effects estimation for a subsample of high income earners. Steinberg et al. (2010) use a random effects tobit model and employ panel survey data which contain information on both household income and wealth from the panel study of income dynamics as well as information on household giving from the center on philanthropy. Tietz and Parker (2014) employ both random-effects probit and tobit models. The data are drawn from the panel study of income dynamics, which is a representative sample of individual Americans and their families.

7 These identifiers include, among others, place of residence, religious affiliation, gender, and realization of different types of income. 
are typically young professionals or retirees, which implies that the average income of the panel is higher than that of the cross-sections. The unit of observation is the single tax return and not the single taxable individual. If married couples choose the option of joint assessment, they get the identical tax identification number and are therefore considered as one observation, so in the following the term 'tax unit' will be used to identify the unit of observation.

The data set contains very detailed information on numerous income and tax variables which - beyond a distinction of the different income sources - allow an accurate computation of the marginal tax rate. From the data we can infer the amount of charitable contributions declared by a tax unit in the income tax return. Moreover, the Taxpayer Panel provides information on several socio-demographic characteristics of the tax units like gender, marital status, age, and the number of children living with the taxpayer. It should be kept in mind, however, that only those individuals who filed an income tax return consecutively for all six years are included in this data set. ${ }^{8}$ For the sake of the analysis we generate the following variables:

Giving. $G$ is the sum of declared charitable donations and membership-fees in the income tax return.

Income Sources. The German income tax law distinguishes income, $I$, from seven different sources summing up to the overall income of a tax unit: income from agriculture and forestry, income from business enterprise, income from self-employment, income from employment, income from capital assets, income from rental and leasing, and other income. ${ }^{9}$ In the baseline specification, we include the natural logarithm of positive income for each income source. As we apply a FEPM (see section 3), we can therefore interpret the point estimates as elasticities. According to the German income tax law, however, it is possible to declare negative income. ${ }^{10}$ This allows for strategic use of different income categories, which may be especially prevalent in the case of income from rental and leasing due to specific allowance contingencies. This effect, however, is not taken into account when we use only positive income. We therefore extend our

8 For the analysis, we further adjust the data by excluding tax units with implausible characteristics (e.g., tax units switching gender or with implausible age), with restricted tax liability (i.e., taxpayers who earn their income in Germany but live abroad), and taxpayers younger than 15 years.

9 'Other income' mainly comprises pension income, but also salaries for parliament membership and income from private disposals.

10 A negative income can either be used for a vertical balancing of losses, i.e., offsetting positive incomes from other sources in the same assessment period, or can be transferred to the following assessment periods. 
model and also include the logarithms of absolute negative income for each of the seven income sources (see column (2) in Table A2 in the appendix).

Tax price of giving. $P$, the tax-determined price of giving is defined as $1-m$, with $m$ being the marginal tax rate. Defined in this way, $P$ measures the taxpayer's opportunity cost of giving in terms of foregone personal consumption. If we take into account the progressivity of the German income tax system, this implies that high income earners face a considerably lower price of giving than low income earners. As the marginal tax rate is a function of taxable income which itself depends on the amount of charitable contributions, we ensure the exogeneity of $P$ by using the 'first-dollar price of giving'. This means that we define $m$ as the marginal tax rate relevant if no donations were made, which is a standard procedure in the literature (Triest 1998; Andreoni 2006). To obtain the marginal tax rate, we apply the tax scales of the years 2001 to 2006 to taxable income plus deductible donations. ${ }^{11}$ Furthermore, all tax units whose donations are below the standard deduction for special expenses, i.e., all non-itemizers, are assigned a price of giving equal to 1 . The so-called borderline itemizers, however, who exceed the standard deduction only as a result of the amount of donations they declare in the income tax return, are excluded from the analysis to maintain exogeneity of the price variable with regard to giving (Clotfelter 1980).

Socio-demographic variables. $X$ summarizes several socio-demographic characteristics of the tax unit such as the assessment status (dummy variables for joint or single filing) and the tax unit's age. The latter is operationalized with age group dummies for age between 15-24, 25-34, 35-44, 45-54 (baseline), 55-64, and more than 65 years. ${ }^{12}$ Furthermore, we include several dummy variables indicating the number of children (one child, two children, three children, and more than three children; tax units without children are the reference category) and information whether the place of residence is in the Eastern (dummy equal to 1) or Western (dummy equal to 0) federal states of Germany.

Time fixed effects. $T$ are time dummy variables to account for time specific effects

11 The German income tax law defines categories of income which are tax exempt but effectively raise average and marginal tax rates. Depending on the relative magnitude of taxable income and tax exempt income, marginal tax rates equal to or larger than 1 may occur. Tax units facing such expropriating taxation are excluded from the analysis as are tax units that exhibit a combination of extra-ordinary income and tax exempt income, which does not permit an unambiguous calculation of marginal tax rates.

12 In case of joint assessment, age refers to the 'principal' income earner. 
that influence the donation decisions of all tax units equally. During our observation period this covers for instance several natural disasters (especially floodings in 2002 and 2006) or macroeconomic effects such as the currency changeover from the Deutsche Mark to the Euro in 2002 .

All monetary values are converted into constant 2006 Euro values using the consumer price index by the German Federal Statistical Office. Descriptive statistics of the control variables are given in the appendix (Table A1).

Figure 1: Share of tax units with income from different sources

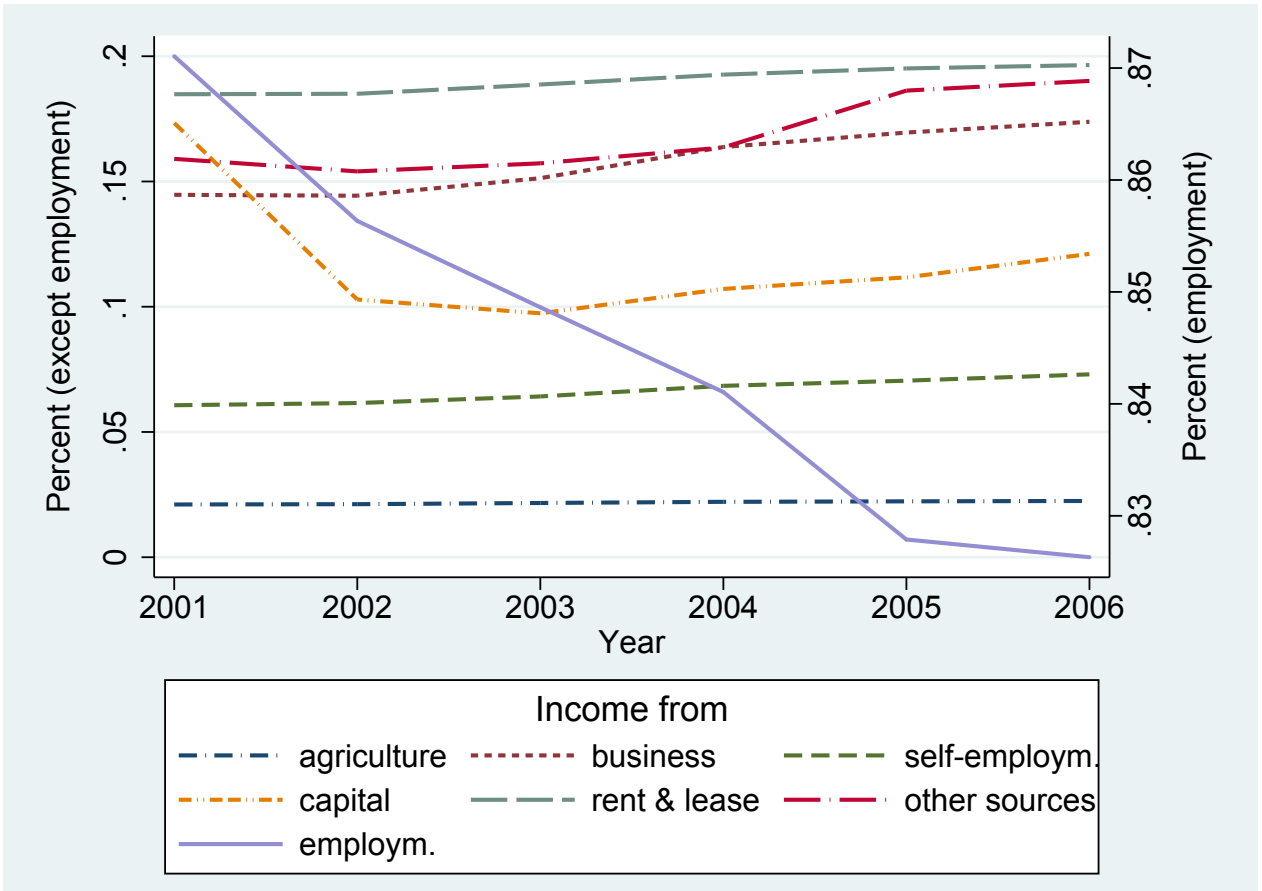

Notes: Percentage shares on the left axis refer to all income sources except income from employment. The latter is depicted on the right axis.

By using aggregate data from the German income tax statistics we can take a look at how the income composition has changed in the period 2001-2006. From Figure 1 it becomes clear that the share of tax units declaring income from employment has continuously decreased from $87.1 \%$ in 2001 to $82.6 \%$ in 2006 (figures for income from employment refer to the axis on the right). Moreover, we observe considerable fluctuations in the share of tax units declaring income from capital assets (figures for remaining income sources refer to the axis on the left). The proportion decreased from $17.3 \%$ in 2001 to $9.7 \%$ in 2003 and went up again to $12.1 \%$ in 2006. In the same period, the share of tax units reporting income from business enterprise and 
income from other sources increased considerably whereas the respective growth in the shares for income from self-employment and income from rental and leasing was more modest.

\section{Estimation and results}

As mentioned above, depending on the research question, we aim to treat solicitations for charitable giving and measurement errors of (business) income due to tax evasion as unobserved heterogeneity. Thus, for both effects we assume an underlying stable pattern, which at least retains for the observational period.

Assumption 1 is that solicitations for charitable donations are constant within a tax unit and differ only between the tax units. Concretely, this assumption allows higher solicitations, e.g., for entrepreneurs or wealthy individuals, which, however, do not vary over time. Thus, the assumption also entails that fundraisers do not react on every change of income or wealth of a tax unit, but rather assess income and wealth in certain intervals and keep their solicitations constant between assessment points.

Assumption 2 is that measurement error of (business) income due to tax evasion is constant within a tax unit and differs only between tax units. In essence, this means that while we control for a higher level of tax evasion by self-employed or business owners, we assume that the evasion pattern is stable over the observational period.

In case of estimating tax evasion, the proposed approach will deliver consistent estimates if assumption 1 holds. Concerning the estimation of entrepreneurial generosity as well as testing the life cycle hypothesis, both assumptions have to be valid to deliver consistent estimates.

When estimating the relationship between different income sources and donations, we face the problem that many tax units report zero donations. This high amount of zeros often motivates the use of Tobit models. However, a consistent Tobit estimation relies on strong assumptions, which are mostly not fulfilled. First, the error term is not normally distributed

and homoskedastic. Second, it is questionable whether the explanatory variables affect the donation decision equally along the extensive and the intensive margin. Third, due to the incidental parameters problem, a fixed effects estimation of the Tobit model is not feasible. Given these problems, researchers often estimate log-linearized OLS models, which allow for 
fixed effects and are generally more robust to violations of model assumptions. However, this model also requires an arbitrary adjustment of the dependent variable. Furthermore, in the presence of heteroskedasticity, the interpretation of log-linearized OLS models can be highly misleading, even when robust standard errors are applied (Silva and Tenreyro 2006). A further alternative, at least for cross sectional data, is an estimation with (unweighted) nonlinear least squares (NLS) as in Feldman and Slemrod (2007). However, from a practical point of view, it is far from trivial to implement fixed effects in a NLS regression with panel data. Moreover, multiplicative NLS models give a higher weight to noisier observations, implying that this estimator may be inefficient and depends heavily on a small number of observations (Silva and Tenreyro 2006).

Given all these econometric difficulties it is astonishing that many researchers investigating charitable donations either stick to the Tobit or the OLS log-linearized model. This is even more so as the fixed effect poisson models (FEPM) offers solutions to the indicated problems. For instance, the FEPM takes the non-linearity of donations data into account and controls for unobserved heterogeneity. Moreover, the FEPM has desirable robustness properties for estimating the parameters in the conditional mean making this model also advantageous compared to simple OLS models. In our case, except for the conditional mean, the distribution of $G$ given the control variables and the fixed effects is completely unrestricted and neither overdispersion nor underdispersion pose a problem for the estimation. Moreover, the model does not require a Poisson distribution and the FEPM also performs well if the proportion of zeros is large (Silva and Tenreyro 2006; Silva and Tenreyro 2011). Finally, the parameter estimates can be directly interpreted as elasticities without the need for arbitrary adjustments to zero donations.

Due to these desirable properties the FEPM has been widely used by researchers in the field of international trade, who are faced with similar data structures of (excess) zeros in the dependent variable and the presence of heteroskedasticity in constant elasticity models (Silva and Tenreyro 2006). However, despite similarities in the data structure and thus common difficulties in econometric analyses, the charity literature to a large extent still focuses to the Tobit model or simple OLS estimation (for an exception using a FEPM with donation data see Reinstein (2011)).

Hence, we estimate the mean of $G_{i t}$ conditional on all covariates $Z_{i t}$ and the fixed effect $\nu_{i}$ 
using the FEPM:

$$
E\left(G_{i t} \mid Z_{i t}, \nu_{i}\right)=\exp \left(\beta_{0}+\beta_{1} I_{i t}+\beta_{2} Y_{i t}+\beta_{3} P_{i t}+\beta_{4} X_{i t}+T_{t}+\nu_{i}\right)
$$

To solve the identification problem originating from the fact that the marginal tax rate is a function of taxable income, we follow Triest (1998) and use an observation period covering several changes in the tax code to obtain exogenous variation in the tax rates. Figure 2 depicts that this is indeed the case for the period from 2001 to 2006.

Figure 2: Variation in marginal tax rates, 2001-2006

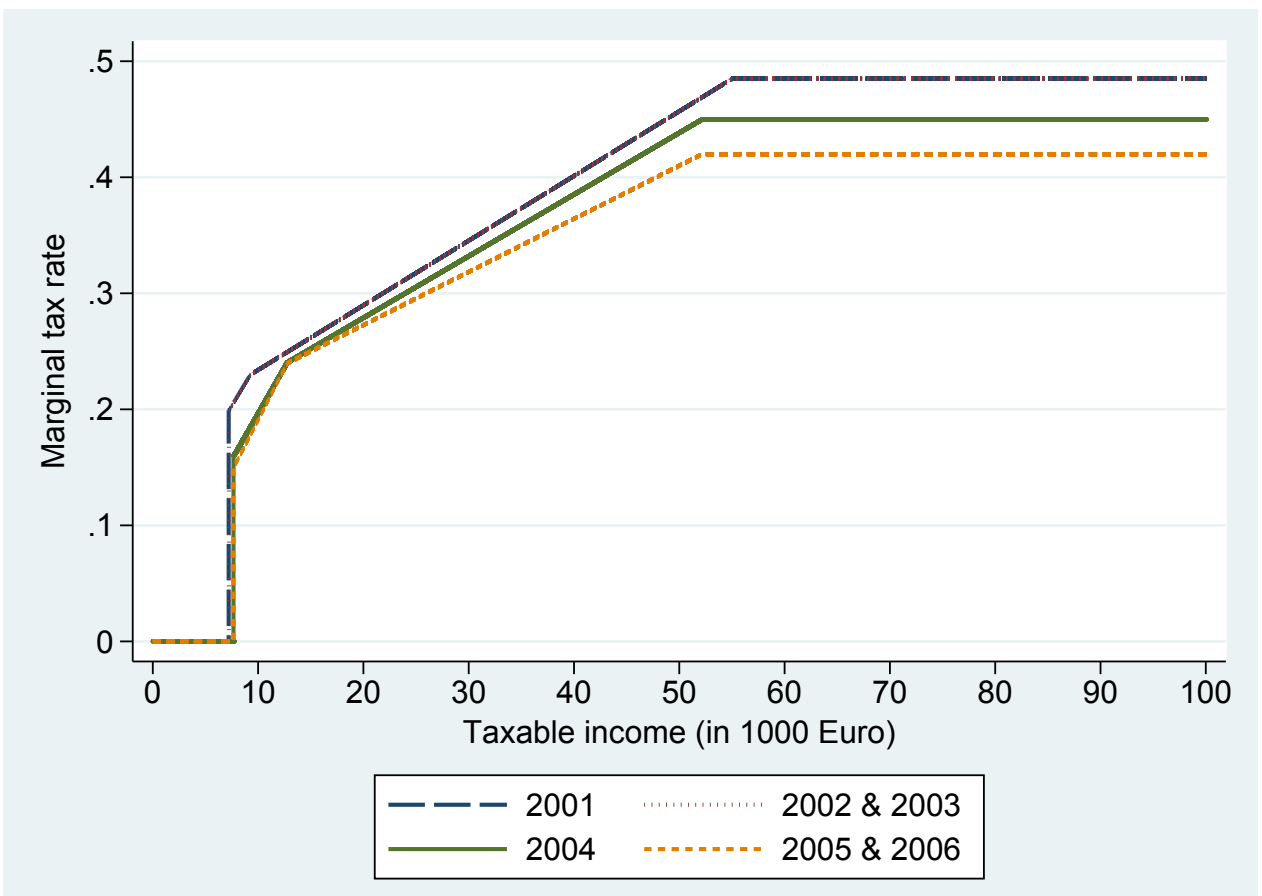

Notes: The figure demonstrates changes in the marginal tax rates for income tax reforms taking place in 2002, 2004, and 2005.

We present the estimation results for the various income sources and the tax price of giving in equation (3). ${ }^{13}$ The full results including control variables are shown in Table A2 in the appendix.

13 The number of observations is $1,597,569$; log pseudolikelihood: $-4.187 \mathrm{e}+08$. Standard errors are shown in paranthesis; ${ }^{*} p<0.05,{ }^{* *} p<0.01,{ }^{* * *} p<0.001$. 


$$
\begin{aligned}
\hat{G}= & \underset{(0.047)}{0.062} \text { Agriculture }+\underset{(0.018)}{0.076^{* * *} \text { Business }}+\underset{(0.023)}{0.038 \text { Self-employment }} \\
& +\underset{(0.009)}{0.004 \text { Employment }}+\underset{(0.007)}{0.040^{* * *} \text { Capital }}+\underset{(0.013)}{0.024 \text { Rent\&Lease }} \\
& -\underset{(0.012)}{0.005 \text { Other }}-\underset{(0.210)}{1.211^{* * *}} \text { Tax Price }+ \text { Control Variables. }
\end{aligned}
$$

The readiness to make charitable contributions differs between the different income sources, even if we control for fixed evasion patterns and solicitations effects of fundraising. In particular business and capital income exhibit a highly significant and positive effect on charitable giving. As the coefficients can be interpreted as elasticities, we estimate that a ten percent increase in business income leads to an increase in charitable donations by approximately $0.8 \%$. A ten percent increase in capital income raises charitable donations by $0.4 \%$. The remaining income sources are not statistically significant at conventional levels. Concerning the economic significance, entrepreneurial income sources such as income from agriculture and self-employment (and also income from rental and leasing) tend to have a positive effect on charitable giving. In contrast, income from employment and income from 'other' sources turn out to be both economically and statistically insignificant. Furthermore, we find a statistically significant elastic effect for the tax price of giving. A ten percent increase in the tax price reduces charitable giving by $12.1 \%$.

In Table A2 in the appendix, we further present results for different effects of positive and absolute negative income. The main results remain, i.e., we find a strong economically and statistically significant effect of income from business and capital on charitable giving. Furthermore, for both income sources, the results reverse for absolute negative income, i.e., if an income loss increases by ten percent, the inclinations to donate decrease by approximately $0.6 \%$ (business income) and approximately 1\% (capital income). We also find such a strong negative effect for absolute negative income from agriculture. 


\section{Discussion and conclusion}

Beyond the pure result that business and capital income are positive and statistically significant determinants of charitable giving, we can now interpret the results in three different ways: First, relying on assumption 1 that the tax unit fixed effects pick up (constant) donation solicitations, we can interpret both coefficients as evasion parameters implying that a $10 \%$ increase in business or capital income increases tax evasion by $0.76 \%$ and $0.4 \%$, respectively. Second, additionally accepting assumption 2 that the fixed effects also cover (time invariant) evasion patterns, the results can be alternatively interpreted that, e.g., a 10\% increase in business income rises donations by $0.76 \%$. Third, we can alternatively reject the fungibility of income with respect to charitable giving as the point estimates differ between income sources. Clearly, this situation is somewhat awkward as generosity and evasion are proportional.

Pertaining to the validity of the assumptions, it seems easier to infer tax evasion from observational or administrative data as only the assumption on fixed solicitation levels has to be fulfilled. Nevertheless, this assumption might still be too strong and, thus, prevents unbiased coefficients. An alternative strategy to the consumption based approach for a detection of tax evasion lies in the identification of a consumption good without solicitation effects, that better reflects the food characteristics of the original Pissarides and Weber (1989) approach than charitable donations. In administrative tax data, for instance, education expenses might be an example as it is hard to argue that beyond an income effect employees or entrepreneurs care differently about the education of their children. Moreover, advertising for education is certainly lower than fundraising for charitable giving and it seems unlikely that the promotion of different educational possibilities is as strategic as professional fundraising.

Concerning the inference of entrepreneurial generosity and the fungibility of income from observational (or administrative) data, the situation is more involved as both assumptions have to be fulfilled. Charitable solicitations are hardly entailed in observational data and certainly not in administrative data, making a direct control difficult. Moreover, as mentioned in the introduction, understated income by entrepreneurs seems to be pervasive. In comparison to the solicitation assumptions it is also more unlikely that fixed effects cover tax evasion, as this would for example rule out that individuals use nonrecurring chances to evade. Therefore, laboratory 
experiments such as Weitzel et al. (2010) or Urbig et al. (2012) seem to be better suited to investigate entrepreneurial generosity or selfishness, as they allow for a better control of the circumstances influencing generosity or selfishness.

For an empirical examination of the life-cycle hypothesis two items have to be considered. As with tax evasion, goods not prone to differing solicitation or advertising effects are more suited to study this question. Moreover, to avoid measurement error of the different income sources, a first step could be to exclude entrepreneurs from the analysis or to explicitly instrument for measurement errors in income sources prone to evasion and under-reporting. 


\section{References}

Acs, Z. J. and R. J. Phillips (2002). Entrepreneurship and philanthropy in American capitalism. Small Business Economics 19(3), 189-204.

Andreoni, J. (2006). Chapter 18 Philanthropy. In S.-C. Kolm and J. M. Ythier (Eds.), Applications, Volume 2 of Handbook of the economics of giving, altruism and reciprocity, pp. 1201 - 1269. Elsevier.

Andreoni, J. and A. A. Payne (2013). Charitable giving. In M. F. Alan J. Auerbach, Raj Chetty and E. Saez (Eds.), Handbook of Public Economics, Volume 5 of Handbook of Public Economics, pp. 1 - 50. Elsevier.

Andreoni, J. and J. M. Rao (2011). The power of asking: how communication affects selfishness, empathy, and altruism. Journal of Public Economics 95, 513-520.

Baumol, W. J. (1990). Entrepreneurship: Productive, unproductive, and destructive. Journal of Political Economy 5(1), 893-921.

Brooks, A. C. (2002). Welfare receipt and private charity. Public Budgeting and Finance 22, $101-114$.

Clotfelter, C. (1980). Tax incentives and charitable giving: evidence from a panel of taxpayers. Journal of Public Economics 13(3), 319-340.

Daneshvary, N. and W. A. Luksetich (1997). Income sources and declared charitable tax deductions. Applied Economics Letters 4, 271-274.

Feldman, N. E. and J. Slemrod (2007). Estimating tax noncompliance with evidence from unaudited tax returns. The Economic Journal 117, 327-352.

Filla, J. J. and H. E. Brown (2013). Identifying new prospects, pp. 15-51. John Wiley \& Sons, Inc.

Hurst, E., G. Li, and B. Pugsley (2014). Are household surveys like tax reforms? Evidence from income underreporting of the self-employed. The Review of Economics and Statistics 96(1), 19-33.

Levin, L. (1998). Are assets fungible? Testing the behavioral theory of life-cycle savings. Journal of Economic Behavior \& Organization 36, 59-83. 
Pissarides, C. A. and G. Weber (1989). An expenditure-based estimate of Britain's black economy. Journal of Public Economics 39(1), 17 - 32.

Reinstein, D. A. (2011). Does one charitable contribution come at the expense of another? The BE Journal of Economic Analysis \& Policy 11(1), Article 40.

Silva, J. S. and S. Tenreyro (2006). The log of gravity. The Review of Economics and Statistics 88(4), 641-658.

Silva, J. S. and S. Tenreyro (2011). Further simulation evidence on the performance of the poisson pseudo-maximum likelihood estimator. Economics Letters 112(2), 220 - 222.

Steinberg, R., Y. Zhang, E. Brown, and P. Rooney (2010). Earned, owned, or tranferred: are donations sensitive to the composition of income and wealth? MPRA Paper (30082).

Tietz, M. A. and S. C. Parker (2014). Charitable donations by the self-employed. Small Business Economics 43, 899-916.

Triest, R. K. (1998). Econometric issues in estimating the behavioral response to taxation: a nontechnical introduction. National Tax Journal 51(n. 4), 761-72.

Urbig, D., U. Weitzel, S. Rosenkranz, and A. van Witteloostuijn (2012). Exploiting opportunities at all cost? Entrepreneurial intent and externalities. Journal of Economic Psychology 33(2), 379 - 393. Personality and Entrepreneurship.

Weitzel, U., D. Urbig, S. Desai, M. Sanders, and Z. Acs (2010). The good, the bad, and the talented: entrepreneurial talent and selfish behavior. Journal of Economic Behavior \& Organization 76(1), 64 - 81. Special Issue: Experimental Methods in Entrepreneurship Research. 


\section{A Appendix}

Table A1: Descriptive Statistics

\begin{tabular}{|c|c|c|}
\hline Variable & Mean & Std. Dev. \\
\hline Giving & 992.7 & 47498.1 \\
\hline \multicolumn{3}{|l|}{ Log positive income from } \\
\hline Agriculture & 0.242 & 1.480 \\
\hline Business & 2.464 & 4.504 \\
\hline Self-employment & 1.892 & 4.083 \\
\hline Employment & 8.990 & 4.135 \\
\hline Capital & 3.592 & 4.244 \\
\hline Rental and leasing & 2.529 & 4.102 \\
\hline Other sources & 1.461 & 3.412 \\
\hline Log tax price of giving & -0.427 & 0.237 \\
\hline Dummy age $15-24$ & 0.013 & 0.112 \\
\hline Dummy age $25-34$ & 0.095 & 0.293 \\
\hline Dummy age $35-44$ & 0.292 & 0.455 \\
\hline Dummy age $45-54$ & 0.299 & 0.458 \\
\hline Dummy age 55-64 & 0.188 & 0.391 \\
\hline Dummy age 65 and above & 0.114 & 0.318 \\
\hline Dummy single female & 0.110 & 0.312 \\
\hline Dummy single male & 0.144 & 0.351 \\
\hline Dummy married, couple & 0.733 & 0.442 \\
\hline Dummy eastern federal state & 0.140 & 0.347 \\
\hline Dummy catholic & 0.412 & 0.492 \\
\hline Dummy protestant & 0.304 & 0.460 \\
\hline Dummy other confession & 0.001 & 0.024 \\
\hline Dummy no confession & 0.284 & 0.451 \\
\hline Dummy no children & 0.465 & 0.499 \\
\hline Dummy one child & 0.199 & 0.400 \\
\hline Dummy two children & 0.245 & 0.430 \\
\hline Dummy three children & 0.072 & 0.259 \\
\hline Dummy more than three children & 0.019 & 0.135 \\
\hline Dummy year 2001 & 0.166 & 0.372 \\
\hline Dummy year 2002 & 0.166 & 0.372 \\
\hline Dummy year 2003 & 0.169 & 0.375 \\
\hline Dummy year 2004 & 0.170 & 0.375 \\
\hline Dummy year 2005 & 0.171 & 0.376 \\
\hline Dummy year 2006 & 0.159 & 0.365 \\
\hline
\end{tabular}

Source: Research Data Centres of the Federal Statistical Office and the statistical offices of the Lnder. Taxpayer Panel 2001-2006, own calculations. All monetary values have been converted into constant 2006 Euro values. The number of observations for each variable is $1,597,569$. 
Table A2: Effect of income from different sources on charitable giving

\begin{tabular}{|c|c|c|}
\hline & (1) & $(2)$ \\
\hline \multicolumn{3}{|l|}{ Log income from agriculture } \\
\hline \multirow[t]{2}{*}{ Positive income } & 0.062 & 0.018 \\
\hline & $(-1.311)$ & $(-0.884)$ \\
\hline \multirow[t]{2}{*}{ Absolute negative income } & & $-0.063^{* *}$ \\
\hline & & $(-2.692)$ \\
\hline \multicolumn{3}{|l|}{ Log income from business } \\
\hline \multirow[t]{2}{*}{ Positive income } & $0.076^{* * *}$ & $0.074^{* * *}$ \\
\hline & $(-4.16)$ & $(-5.591)$ \\
\hline \multirow[t]{2}{*}{ Absolute negative income } & & $-0.061^{* * *}$ \\
\hline & & $(-5.478)$ \\
\hline \multicolumn{3}{|c|}{ Log income from self-employment } \\
\hline \multirow[t]{2}{*}{ Positive income } & 0.038 & 0.013 \\
\hline & $(-1.626)$ & $(-1.484)$ \\
\hline \multirow[t]{2}{*}{ Absolute negative income } & & $-0.025^{*}$ \\
\hline & & $(-2.037)$ \\
\hline \multicolumn{3}{|l|}{ Log income from employment } \\
\hline \multirow[t]{2}{*}{ Positive income } & 0.004 & -0.012 \\
\hline & $(-0.518)$ & $(-0.944)$ \\
\hline \multirow[t]{2}{*}{ Absolute negative income } & & 0.015 \\
\hline & & $(-1.241)$ \\
\hline \multicolumn{3}{|l|}{ Log income from capital } \\
\hline \multirow[t]{2}{*}{ Positive income } & $0.040^{* * *}$ & $0.048^{* * *}$ \\
\hline & $(-5.963)$ & $(-5.752)$ \\
\hline \multirow[t]{2}{*}{ Absolute negative income } & & $-0.097^{* * *}$ \\
\hline & & $(-4.324)$ \\
\hline \multicolumn{3}{|c|}{ Log income from rental and leasing } \\
\hline \multirow[t]{2}{*}{ Positive income } & 0.024 & 0.007 \\
\hline & $(-1.837)$ & $(-0.573)$ \\
\hline \multirow[t]{2}{*}{ Absolute negative income } & & -0.002 \\
\hline & & $(-0.201)$ \\
\hline \multicolumn{3}{|l|}{ Log income from other sources } \\
\hline \multirow[t]{2}{*}{ Positive income } & -0.005 & -0.027 \\
\hline & $(-0.443)$ & $(-1.420)$ \\
\hline \multirow[t]{2}{*}{ Absolute negative income } & & 0.026 \\
\hline & & $(-1.406)$ \\
\hline
\end{tabular}


Table A2 (continued)

\begin{tabular}{|c|c|c|}
\hline & (1) & $(2)$ \\
\hline Log tax price of giving & $\begin{array}{c}-1.211^{* * *} \\
(-5.777)\end{array}$ & $\begin{array}{r}-0.915^{* * *} \\
(-3.670)\end{array}$ \\
\hline Dummy single female & $\begin{array}{c}-0.502^{* * *} \\
(-3.478)\end{array}$ & $\begin{array}{c}-0.535^{* * *} \\
(-4.226)\end{array}$ \\
\hline Dummy single male & $\begin{array}{l}-0.027 \\
(-0.212)\end{array}$ & $\begin{array}{c}-0.092 \\
(-1.439)\end{array}$ \\
\hline Dummy married, separate assessed & $\begin{array}{l}-0.286^{*} \\
(-2.104)\end{array}$ & $\begin{array}{c}-0.187 \\
(-1.800)\end{array}$ \\
\hline Dummy age $15-24$ & $\begin{array}{l}0.535^{* *} \\
(-2.672)\end{array}$ & $\begin{array}{l}0.531^{* *} \\
(-2.962)\end{array}$ \\
\hline Dummy age $25-34$ & $\begin{array}{l}-0.198 \\
(-1.534)\end{array}$ & $\begin{array}{l}-0.029 \\
(-0.269)\end{array}$ \\
\hline Dummy age $35-44$ & $\begin{array}{l}-0.041 \\
(-0.487)\end{array}$ & $\begin{array}{c}-0.012 \\
(-0.238)\end{array}$ \\
\hline Dummy age 55-64 & $\begin{array}{l}-0.098 \\
(-0.871)\end{array}$ & $\begin{array}{c}0.022 \\
-0.225\end{array}$ \\
\hline Dummy age 65 and above & $\begin{array}{c}0.400^{*} \\
(-2.356)\end{array}$ & $\begin{array}{l}0.304^{*} \\
(-2.07)\end{array}$ \\
\hline Dummy eastern federal state & $\begin{array}{l}-0.063 \\
(-0.764)\end{array}$ & $\begin{array}{l}-0.238^{*} \\
(-2.091)\end{array}$ \\
\hline Dummy catholic & $\begin{array}{l}-0.079 \\
(-0.889)\end{array}$ & $\begin{array}{l}-0.187^{*} \\
(-2.364)\end{array}$ \\
\hline Dummy protestant & $\begin{array}{l}-0.105 \\
(-0.866)\end{array}$ & $\begin{array}{c}-0.05 \\
(-0.565)\end{array}$ \\
\hline Dummy one child & $\begin{array}{l}0.138^{* *} \\
(-2.805)\end{array}$ & $\begin{array}{c}-0.005 \\
(-0.103)\end{array}$ \\
\hline Dummy two children & $\begin{array}{l}0.238^{* * *} \\
(-3.951)\end{array}$ & $\begin{array}{c}0.150^{*} \\
(-1.974)\end{array}$ \\
\hline Dummy three children & $\begin{array}{c}0.199^{*} \\
(-2.534)\end{array}$ & $\begin{array}{c}-0.147 \\
(-0.832)\end{array}$ \\
\hline Dummy more than three children & $\begin{array}{l}0.417^{* *} \\
(-3.164)\end{array}$ & $\begin{array}{c}-0.139 \\
(-0.613)\end{array}$ \\
\hline Dummy year 2002 & $\begin{array}{c}0.141 \\
(-1.739)\end{array}$ & $\begin{array}{c}0.125^{*} \\
(-2.185)\end{array}$ \\
\hline
\end{tabular}

Continued on next page. 
Table A2 (continued)

\begin{tabular}{lcc}
\hline & $(1)$ & $(2)$ \\
\hline Dummy year 2003 & 0.047 & 0.073 \\
& $(-0.61)$ & $(-1.234)$ \\
Dummy year 2004 & 0.111 & $0.171^{* *}$ \\
& $(-1.625)$ & $(-2.68)$ \\
Dummy year 2005 & $0.344^{* * *}$ & $0.382^{* * *}$ \\
Dummy year 2006 & $(-4.717)$ & $(-5.641)$ \\
& $0.340^{* * *}$ & $0.426^{* * *}$ \\
Observations & $(-3.709)$ & $(-6.741)$ \\
Log pseudolikelihood & $1,597,569$ & $2,700,659$ \\
\hline
\end{tabular}

$t$-statistics are shown in parentheses.

${ }^{*} p<0.05,{ }^{* *} p<0.01,{ }^{* * *} p<0.001$.

Absolute negative values are used in case of negative income. 